\section{Estudo descritivo da avaliação da transmissão congênita da doença de Chagas em três instituições da cidade de São Paulo}

A doença de Chagas, sua etiologia e as primeiras referências da transmissão congênita foram descritas no início do século por Carlos Chagas. O controle da transmissão vetorial da doença de Chagas iniciou-se à época dos primeiros grandes movimentos migratórios no país, e esta deixou de ser a principal via de transmissão da doença na década de oitenta, aumentando assim a importância da via de transmissão congênita, que até então havia sido pouco estudada. No presente trabalho avaliamos a possibilidade da transmissão congênita em estudo realizado com 57 gestantes chagásicas crônicas, sendo 55 provenientes de regiões endêmicas; $47,4 \%$ dos casos apresentavam a forma indeterminada, $43,8 \%$ a forma cardíaca e $8,8 \%$ a forma digestiva da doença de Chagas. As gestantes foram selecionadas de três instituições de referência de alto risco na cidade de São Paulo, capital: Hospital-Maternidade Leonor Mendes de Barros, Setor de Cardiopatia e Gravidez do Instituto Dante Pazzanese de Cardiologia e Disciplina de Obstetrícia do Departamento de Ginecologia e Obstetrícia da Faculdade de Medicina da Universidade de São Paulo. A pesquisa de Trypanosoma cruzi circulante foi efetuada nos conceptos ao nascer, utilizando-se a técnica do microhematócrito, do QBC (quantitative buffy coat) e do xenodiagnóstico in vitro. O método parasitológico foi capaz de diagnosticar dois casos de recém-nascidos com infecção congênita, sendo ambos filhos de mães chagásicas com co-infecção pelo HIV. Os dados da pesquisa de anticorpos $\operatorname{lgG}$, realizada por ELISA, utilizando-se 3 antígenos distintos do Trypanosoma cruzi (de formas epimastigotas, de formas tripomastigotas e com antígenos recombinantes), mostrou uma relação estatisticamente significativa entre os títulos maternos e infantis ao nascimento. A pesquisa de anticorpos IgM e lgG nos recém-nascidos foi realizada pela técnica de Western-blotting, utilizando-se um purificado de formas

\title{
Descriptive study of the assessment of congenital transmission of Chagas' disease in three institutions in the city of São Paulo
}

The first reference to the congenital transmission of Chagas' disease was described in the beginning of the century by Carlos Chagas. The control of the vectorial transmission of Chagas' disease began at the same time of the first great migratory movements in Brazil. In the 80's the vectorial route of transmission of Chagas' disease decayed, increasing thus the importance of congenital transmission. In the present study we evaluated the possibility of congenital transmission of Chagas' disease in a group of 57 pregnant women with chronic Chagas' disease. Among them, 55 were from endemic areas; and $47.4 \%$ presented the indeterminate form, $43.8 \%$ the cardiac form and $8.8 \%$ the digestive form of Chagas' disease. The pregnant women were selected from three institutions of reference in São Paulo city: Hospital-Maternidade Leonor Mendes de Barros, Setor de Cardiopatia e Gravidez, Instituto Dante Pazzanese de Cardiologia and Disciplina de Obstetrícia do Hospital das Clínicas da Faculdade de Medicina da Universidade de São Paulo. The presence of Trypanosoma cruzi was assessed in the newborns at birth, by: microhematocrit, QBC (quantitative buffy coat) and xenodiagnosis in vitro. The parasitolological methods were able to diagnose two cases of congenital T. cruzi infection, both born from chagasic woman co-infected with HIV. The ELISA data for $\lg G$ assessment was performed using three different antigens from T. cruzi, $Y$ strain: extract from total epimastigote forms (Epi), tripomastigote purified fractions (TESA) and proteins obtained by recombinant DNA technology. The results showed a significant relationship among the maternal and infantile titles at birth. The $\lg M$ and $\lg G$ assessment in the newborn were done by Western-blotting method using purified forms of tripomastigote fractions as antigen. Out of two parasitological positive cases only one was positive for the detection of $\lg G$ and $\lg M$. The other case were

Recebido para publicação em 19/8/98. 
tripomastigotas como antígeno, resultando positiva em um dos dois casos parasitologicamente positivos. Em um destes casos, concepto de mãe chagásica com co-infecção pelo HIV, não foram detectados anticorpos IgG circulantes, apesar dos inúmeros parasitas circulantes, detectados pelo exame direto. A pesquisa de $T$. cruzi nos tecidos pelo método de imunohistoquímica foi positiva em um caso de feto macerado de 14 semanas e em uma placenta e cordão umbilical de um natimorto macerado; as duas placentas dos filhos de mãe chagásica com co-infecção pelo HIV revelaram positividade para T. cruzi e antígeno p24 do HIV. A transmissão vertical do $T$. cruzi foi comprovada em quatro (7,01\%) casos dos 57 estudados. not detected in spite of the countless circulating parasites, detected by direct exam of a drop of blood under microscope. The detection of T. cruzi antigens, in tissue by immunocytochemistry, was positive in one 14-week old macerated fetus and in a placenta and umbilical cord of a macerated stillborn; both placentas of mothers with HIV and $T$. cruzi co-infection revealed positivity for T. cruzi and HIV p24 antigen by the same method. The vertical transmission of Chagas' disease was proved in four $(7.01 \%)$ of the 57 studied cases.

Isabele Vera Vischr Nisida

Dissertação apresentada à Faculdade de Medicina da Universidade de São Paulo para obtenção do Título de Mestre.

São Paulo, SP, Brasil, 1998. 